\title{
During Credo He Shouted "Blessed be [...]; now I can hear": Nordic Child Miraculees Interacting with Liturgy
}

\begin{abstract}
This article focuses on miracle narratives associated with saints originating in the Nordic region, written from the 12th to the 15th century, where a rich collection of images of children present around and inside of churches and at shrines can be found. Many of the tales portray children in devotional activities, giving an indication of how children moved and acted in these spaces. The events described often transpire during prayers and services, and show how children were seen and heard in spaces where liturgical activity shaped the rhythms of the day and the year. By examining how children are presented, as present and participating in these spaces, and by noting the bits of sensory information given in the narratives, this article adds to our mental image of the religious practices as well as sensory experiences of medieval children.
\end{abstract}

In Sancti Willelmi Abbatis vita et miracula, written in the mid $13^{\text {th }}$ century, we are told that on a feast day in the beginning of that same century a large crowd of pilgrims, both male and female, had sought out the shrine of Wilhelm the Abbed at Æbelholdt in Denmark. His shrine was located inside a wooden church and on that day one such pilgrim, a mother, came carrying a small child on her arm. The child was blind due to a horrible-looking ulcer, but as the custodian of the saint's relics touched the ulcer with the saint's tooth and cleaned it with the bone-water in which the relics had been washed, it ruptured, and pus discharged from it until the girl could again see clearly. In seemingly spontaneous response to this, the crowd that witnessed the miracle burst into praise of God. ${ }^{1}$

In the last decades hagiographic material like this miracle story has been increasingly used and valued as historical source material that offers access to the daily life and lived religion of the laity. Social historians in particular have used miracle collections extensively, but their interest has often been directed towards other aspects of the text than those concerning medieval religiosity. This holds true also for the study of children and childhood in the Middle Ages, in which interesting studies have been carried out on, for example, disability, ${ }^{2}$ illness

\footnotetext{
${ }^{1}$ Sancti Willelmi Abbatis vita et miracula. Gertz 1908, 355.

${ }^{2}$ Metzler 2006; Metzler 2013; Kuuliala 2013.
} 
and accidents, ${ }^{3}$ parental grief and parent-child relations. ${ }^{4}$ Recently, however, scholars have begun drawing more attention to the fact that miracle collections are religiously inspired texts, rather than primarily registers of historical incidents, and thus striving to take the full hagiographic function and context of the narrative sources into account. ${ }^{5}$ Miracles represent a type of tale that was told and retold all through the Middle Ages, and that helped shape medieval worshippers' understanding of and devotion to the sacred. Because of this they have also been suggested as particularly useful sources through which to uncover medieval patterns of cognition and perception. ${ }^{6}$

In this article Nordic miracle narratives about child miraculees and their actions are studied as a source of religious practices as well as sensory experiences at the locations of Nordic medieval shrines. The relationship between the miracle narratives and actual events is complex, and they are not sources that give us direct access to actual habits or events. They may be more reliable as religious text sources to the authors' conceptions of children, but they are nevertheless products of direct or indirect interaction with children. ${ }^{7}$ As such they may also give some access to the outward, observable actions of medieval children themselves and give cumulative insights into what is said to be common practices of parents and children at the medieval shrines.

The potentially disruptive qualities of miracles taking place at shrine locations have been addressed before, for instance in studies of specific cults, ${ }^{8}$ women's lament, ${ }^{9}$ and bodily fluids. ${ }^{10}$ They have been interpreted as a reminder of the unpredictability of divine activity, ${ }^{11}$ and, curiously, simultaneously as culturally prescribed devotional practices and unwanted disruptive incidents. ${ }^{12}$ However, to date there are no studies of narratives about children on pilgrimage who participate in the devotional activities at shrines, and who interact with or disrupt the liturgy with displays of miraculous cures, perhaps diverting the attention of the congregation and the clergy from the ordinary services of the church to what can be considered performances of divine intervention. The main objective of the study presented here, is to explore ways in which narratives about the actions of child miraculees may add to our understanding of the multisensory religious rituals of the Middle Ages, specifically with a view towards the role children play in hagiographic texts, and particularly when they are portrayed as participants in the activities taking place at shrines.

\section{Nordic stories about children at the shrine and the selection of miracle texts}

Among the early $15^{\text {th }}$-century miracles of the holy bishop Saint Brynolf of Skara, found in his canonization hearing from 1417 , there is a miracle story concerning the four-year-old daughter of a man named Ingewald. She is told to be a gravely ill girl who is brought by her parents

\footnotetext{
${ }^{3}$ Finucane, 1997.

${ }^{4}$ Krötzl 1989; Aldrin 2015.

${ }^{5}$ See for example: Bailey 2017, 267; Mesley 2014; Craig 2009, 84-85.

${ }^{6}$ Lohfert Jørgensen 2015, 33-34.

${ }^{7}$ Zottl 2006, 4.

${ }^{8}$ Gaposchkin 2010.

${ }^{9}$ Bailey 2013.

${ }^{10}$ Nugent 2001.

${ }^{11}$ Nugent 2001, 69-70.

${ }^{12}$ Bailey 2013, 537-540.
} 
to the grave of Brynolf, which was located inside Skara Cathedral in Sweden. There she sleeps for an hour before she wakes up and starts running around, completely healed. ${ }^{13}$ This miracle story, which paints a picture of a cheerful and light-hearted child running around inside Skara Cathedral, is typical of the stories explored in this article in that it locates the child's activities, as well as the miracle, at the shrine itself. Because of this, it also conveys ideas about movement and sound that may have disturbed, disrupted or accompanied liturgical activities in the cathedral.

Child miraculees make up between a third and a fourth of the miraculees described in Nordic miracles, ${ }^{14}$ and in the earlier Scandinavian miracle collections shrines are the dominant location for healings. In the later collections, the healings also happen to a greater extent away from the shrines. The majority of the more than 50 Scandinavian shrine-side miracles with child or adolescent miraculees are found in the Latin $12^{\text {th }}-13^{\text {th }}-$, and early $14^{\text {th }}$-century miracle collections, which are comprised of primarily Norwegian and Danish miracles. Unlike the miracle story rendered above, Swedish miracles of the late $14^{\text {th }}$ and $15^{\text {th }}$ centuries, and also Icelandic miracles in the vernacular from the $13^{\text {th }}$ century, are to a much greater degree distance miracles, that is, miraculous events that are reported to have transpired at locations other than the shrine.

This development corresponds to a trend pointed out by Vauchez, amongst others, of miracles more and more frequently taking place away from the shrine in the later Middle Ages. ${ }^{15}$ Vauchez traces this development in continental miracle collections to the $13^{\text {th }}$ and $14^{\text {th }}$ centuries, and claims that it is in part a result of the disassociation of the cults of the saints from their tombs due to the dissemination of icons. The Icelandic $13^{\text {th }}$-century miracles conform with this continental trend and, with the exception of four child miraculees in the miracles of Saint Thorlak, ${ }^{16}$ they feature children that are healed away from the shrine. In the rest of the Scandinavian miracle collections the same development appears to happen a little later. ${ }^{17}$ Consequently, it is especially in the earliest Scandinavian miracle stories from the $12^{\text {th }}$ and $13^{\text {th }}$ centuries that we encounter miracles where children are described as having dramatic healings at the shrine, in front of crowds of witnesses present at the church, and during feasts and processions.

But the presence of children at the shrine did not end as a result of moving the main site of miracles with child miraculees away from the shrine. Even with the increased prominence of home cures, children's presence at the church is still attested to in the miracles. They are not only featuring as part of the crowd attending masses or feast, or as visitors arriving on a pilgrimage of thanksgiving to offer thanks and votive gifts after some miracle, but also in more focal roles, especially when the healed children are presented as proof that miracles have occurred, often during feasts and sometimes in front of large audiences. ${ }^{18}$

\footnotetext{
${ }^{13}$ Vita sancti Brynolphi episcopi Scarensis cum processu eius canonizacioni. Fant 1876, 144.

${ }^{14}$ Krötzl 1989, 25-26; Myrdal and Bäärnhielm 1994, 53-54; Fröjmark 1997, 31.

${ }^{15}$ Vauchez 1997, 446-452.

${ }^{16}$ Skórzewska 2008, 106-107.

${ }^{17}$ For a breakdown of shrine-side and distance miracles in Scandinavian miracles see: Krötzl 1994, 186-187, 244-245. (Note that the number of distance miracles for Brynolf of Skara and Nicholaus of Lincoping have been swapped in the graph).

${ }^{18}$ Examples of healed children being shown to crowds can be found in several of the Scandinavian miracle collections. For example, in several miracles of St. Eric of Sweden. Fant 1828, 282.
} 
Differences between the collections of miracles are not only related to their country and century of origin or the locations where the miracles transpire, but also to the type of miracle collection we are dealing with. Miracles can be found in locally produced legendaries, notarial records, chronicles, vitae, shrine books and canonization records. ${ }^{19}$ The earlier collections usually consist of tales of miracles recorded in shrine books at the shrines of saints, which were then sometimes later rewritten in a more literary form. ${ }^{20}$

Many scholars have observed that the miracula genre changed in significant ways during the medieval period. ${ }^{21}$ These changes were to a large extent driven by the increased documentation demands that resulted from the developments of the formal canonization processes. As a result of such demands miracles recorded in connection with canonizations are often characterized by being richer in detail than their more informal counterparts and by including more information about environmental, social and circumstantial topics. ${ }^{22}$

Consequently, many historians have preferred these sources to the earlier miracle collections for their supposed greater detail, and some scholars have claimed that the later Scandinavian miracle collections are more suited for socio-historical analysis than the earlier ones. ${ }^{23}$ This might be the case. However, for the purposes of exploring the devotional activities of children at the church and shrine and in other sacred spaces, and especially with regards to the interplay between the activities of the children and the liturgy, the canonization hearings often provide less information than the older collections. Especially in the earlier Scandinavian miracle stories we encounter several clear examples of children being seen and heard. We are told about the actions of children present and involved during the ritual activity of the church, and we hear of children who become the centre of attention for the present laity as well as the clergy as they are miraculously healed.

The majority of the narrative examples I focus on here are from Scandinavian miracle collections written from the mid $12^{\text {th }}$ to the early $14^{\text {th }}$ century. In addition, there is one striking exception to the mainstream tendency of moving away from the shrines - namely the early $15^{\text {th }}$ century canonization process of Brynolf of Skara, in which the aforementioned miracle of the running four-year-old girl takes place. In this late medieval collection and canonization record, a significant proportion of the miracles are reported to have happened shrine-side. ${ }^{24}$ Vauchez describes the cult of Brynolf (d. 1317) as a clerical "construct". ${ }^{25}$ In the first hundred years after his death there was no cult associated with him, and miracles did not begin to be reported until his exhumation and translation in $1404 .{ }^{26}$ According to the Acta et processus canonizacionis Beate Birgitte, St Birgitta visited the cathedral at Skara and noticed a sweet scent emanating from his tomb, she then had a vision of Mary confirming that Brynolf was intended for sainthood. ${ }^{27}$ It seems likely that the unusual number of shrine-side healings for

\footnotetext{
${ }^{19}$ Goodich 1995, 7.

${ }^{20}$ Ward 1987, 33-35.

${ }^{21}$ Vauchez 1997, 1-8; Finucane 1977, 49-55.

${ }^{22}$ Goodich 2007, 87-94.

${ }^{23}$ Krötzl 1989, 24-25; Fröjmark 2012, 299.

${ }^{24}$ Krötzl 1994, 91.

${ }^{25}$ Vauchez 1997, 224-225.

${ }^{26}$ Vauchez 1997, 224.

${ }^{27}$ Collijn 1924, 531.
} 
this time period found in the Brynolf miracles are a direct result of the circumstances surrounding the establishment of this cult.

Along the lines sketched above, the specific stories used as examples below are selected for the information they provide about a) the locality, time and space of ongoing liturgical activities and how the narrated miracle transpires in relation to it; b) foregrounded sensory experiences such as seeing and hearing and the tactile aspects of miracles; and c) children's activities and interruptions, especially those of the children themselves and, by extension, also those of parents who bring children into the sacred space in search of divine interventions and healings.

\section{Liturgy as context and temporal setting}

Given the frequency of masses and canonical prayers, it is not surprising that many miracles are presented as occurring inside of shrine churches or cathedrals while some sort of liturgical activity was going on. The miracles in these narratives are by nature unanticipated, hoped and prayed for, but not expected. Consequently, they cannot have been a formal part of the liturgy. The miracles found in these narratives do, however, co-exist in the same time and space as the liturgical activities, and they transpire in some kind of relation to these practices. A pertinent question to ask is therefore whether or not the events told in these stories, and the child miraculees themselves, should be understood as interruptions and disturbances, or if the narrative construction of the stories can be said to imply interplay and interaction between the rituals of the church and the seemingly spontaneous miracle.

An example of interplay between the miraculous event and the liturgy is found in a miracle attributed to St. Knud of Denmark. ${ }^{28}$ We are told that a little boy called Hesbernulus, who was deformed and lame, had crept on his arms to the shrine of St. Knud and was healed there after a vision of the saint. Upon seeing this, the congregation responded by singing the responsorium from the office of the saint, "the Lord led the just" in celebration. ${ }^{29}$ This example illustrates a seemingly unclear divide or boundary between official liturgical practice and the para-liturgical or even non-liturgical activities of laypeople in the Middle Ages. ${ }^{30}$ The child becomes the centre of attention while part of the saint's responsorium is being sung, and the liturgy is employed by what seems to be the laity in order to celebrate the saint's - and God's - intervention on behalf of the child.

It is not unusual for miracle stories to mention the singing of mass or the passing of canonical hours, thus making it clear that the sounds, smells and rhythms of the liturgy would be a continuous backdrop as the miracle-seekers slept, waited and prayed at the shrines. However, the liturgy does not simply provide the background to, or the framing of, the miraculous event. In many miracles the explicit mentioning of canonical prayers, feasts or specific parts of the mass also provide temporal information that may provide us with important cues to contextualize the miracle, for example attesting to the time span of a pilgrim's stay at the shrine.

\footnotetext{
${ }^{28}$ Passio sancti Kanuti regis et martyris. Gertz 1908, 554.

29 “[...] et conuentus hec videns cantauit responsorium: 'Iustum deduxit Dominus'. Passio sancti Kanuti regis et martyris". Gertz 1908, 554.

${ }^{30}$ Flanigan 2005, 699.
} 
A good example is found in a miracle of Saint Niels of Århus, from the mid $13^{\text {th }}$ century:

A woman from the parish came to the priest Johannes of Randers after mass. She was carrying a three-year-old boy deprived of sight by a terrible ulcer. She said that she had heard in her sleep someone advising her to go barefoot to the saint Niels in Århus with the boy, and so she sought the priest's advice. At that time, she showed that the boy's eye was pushed out and was hanging with his torn jaw down to his chin.

She came to the holy Niels while vespers were being sung, and when she had poured out her prayer to his grave the boy fell asleep. After compline, the guardian [of the shrine] said: "Take the boy and leave!" Crying she carried the sleeping child to the guesthouse [hospitium] and spent the night there. In the morning, she returned home and still the boy did not wake up. Neighbours arrived, and she untied his head, and they found him completely healed. ${ }^{31}$

The three-year-old boy in this story is said to fall asleep during vespers. He is still asleep when the mother is made to leave the church after compline, he sleeps through the night they spend at the hospice and all the way home during their return to Randers the next morning (a distance of around $40 \mathrm{~km}$ ), never told to be disturbed or woken by all that happens around him.

The child in the miracle rendered above is not portrayed as disruptive. Notwithstanding an ulcer that most likely would have been utterly painful, he is not said to fuss or cry or draw attention to himself. Rather, he conveniently falls into a deep sleep shortly after he arrives at the shrine of Saint Niels. The disruptive element in this tale is the mother who brings the child into the church. She arrives while vespers are being sung and proceeds to profusely pour her prayers out to the shrine of the saint. The little boy is more of a prop than a protagonist, carried around by the mother all through the narrative. He is indeed the one who is miraculously cured, but it is the mother who gets a message and acts upon it, it is her grief, her hope and her prayers that are accentuated in the tale. This is a common trait in miracles featuring children. Infants, toddlers and also older children who are unconscious or physically or mentally impaired, are brought to the shrine with little or no ability to decide for themselves if they want to go on a pilgrimage. In this respect they may be conceived of as passive pilgrims.

It is interesting to note that the mother is not said to re-enter the church for another day of prayer, even though the story gives us reason to believe that at this point she does not know whether the child is healed or not. The healing transformation or restoration is obscured due to the bandages and not revealed until the mother and son are at home, where she unwraps the child's face in front of the neighbours. Accordingly, while all the other miracle stories included here feature miracles that are undoubtedly carried out as shrine-side healings, in this case we cannot confirm whether or not the actual healing is said to be completed at the shrine, though, as in the other cases the shrine still functions as a kind of faith-healing centre. $^{32}$

The miracle story about the little boy at Saint Niels' shrine is a story of incubation, that is, a narrative about sleeping in a sacred space in the hope of receiving a cure or a vision. This is a noteworthy trait of many tales about Nordic children miraculees. In our example we also

\footnotetext{
${ }^{31}$ My translation based on De Vita et Miraculis B. Nicholai Arusiensis, Gertz 1908, 402; Olrik 1893, 304.

${ }^{32}$ Krötzl 1989, 33-34.
} 
observe detailed information about the length of time that the boy and mother spend in the church as pilgrims, through two canonical prayers. Often the duration of the incubation or the stay at the grave is not given. However, some cases include similar information about the duration of the child's stay, often with liturgical hours functioning as temporal signposts. Two of them are from the miracles of Saint Brynolf. The first one is the story about the gravely ill four-year-old girl mentioned above, who sleeps at the grave of Brynolf for an hour before she wakes up and starts running around. ${ }^{33}$ The second is the story of a mute infant boy whose limbs are so severely crippled that his hands are stuck to his chest. He arrives with his parents at prime and is healed before the start of vespers. ${ }^{34}$ A third example of incubation which supplies information about time-frame and duration is from the $12^{\text {th }}$ century and found in Passio et miracula beati Olaui. In this story a mute boy whose tongue has been cut out, sees the saint in a dream vision after remaining steadfastly at the tomb where he has slept several times before the particular sleep in which he sees the saint appear. ${ }^{35}$

In continental miracle collections, pilgrims and miracle-seekers are often reported to stay at the holy location for several days. ${ }^{36}$ This does not seem to be customary in the Nordic miracles concerning children, or at least such extended stays are rarely explicitly mentioned. The children from the three examples concerning Saint Niels and Saint Brynolf are typical in this respect. They are all reported to stay and sleep at the respective shrine for a limited time. The boy in the miracle story from Passio et miracula beati Olaui is the only example I have come across where the miraculee is said to have stayed at the shrine for a considerably longer period of time, probably for days. In the other examples mentioned above, liturgical activities such as vespers and compline function as temporal signposts for our interpretation of the time spent at the shrine by children and their parents.

\section{Multisensory miracles}

It has been claimed that among the senses sight played the most important role in inspiring faith in the Middle Ages. ${ }^{37}$ Generally, sight is also the sense that is most often emphasized in stories about child miracles: Miraculous healings are perceived visually and reported as having been seen by those witnessing the miracles, visions are seen by the miraculee while sleeping at the shrine, the holy site is sought and seen, and the saint's relics or shrine are in sight. But sight is by no means the only sense in play in the narrative examples I focus on here.

In this article's introductory miracle from the shrine of Wilhelm the Abbed, which features the girl with the ulcer, multiple senses are in play. We hear about the girl's blocked and later restored eyesight; we can easily imagine the grotesque sight of her ulcer and its transformation as it bursts and pus is discharged until the girl is healed and can see again; and the touching of the relic and the contact-relic amounts to a layering of tactility as the pilgrim and her ulcer are touched with something that has itself touched the saint's relics. One can even imagine the smell that most surely must have issued from the infected ulcer. Still, the most

\footnotetext{
${ }^{33}$ Vita sancti Brynolphi episcopi Scarensis cum processu eius canonizacionis. Fant 1976, 144, 170.

${ }^{34}$ Vita sancti Brynolphi episcopi Scarensis cum processu eius canonizacionis. Fant 1976, 144, 173-174.

${ }^{35}$ Passio et miracula beati Olaui, Jiroušková 2014, 37-38.

${ }^{36}$ Gaposchkin 2010, 256-257; Vauchez 1997, 444-445.

${ }^{37}$ Hahn 1997, 1079.
} 
salient sensorial experience for the witnesses imagined to be part of this story, would probably be the sound of the rejoicing congregation.

The sheer amount of noise produced by praying and celebrating petitioners has been commented on by other scholars writing about the relationship between miracles and liturgy. ${ }^{38}$ The miraculee would scream, groan and cry, and sometimes fill the church with distracting noise. ${ }^{39}$ Many of the children encountered in my examples do cause commotions in the sense that they are told to call attention to themselves by being visibly and auditorily disruptive. Such sounds from children present at churches and shrines may easily be conceived of by modern readers as unwelcome in a sacred space, that is, as elements of disorder and interference that should be stifled and managed. There is a witness deposition given in connection with another healed four-year-old girl from the miracle collection of St Brynolf, where the custodian and witness twice emphasizes that this miracle is both seen and heard by himself and by the large crowd present in the cathedral at the time. ${ }^{40}$ Yet, while some sources for example lament that women in churches were sometimes considered excessively noisy and shushed, ${ }^{41}$ nowhere in my material are the sounds produced by the children described as problematic or intrusive.

In a miracle from Passio et miracula beati Olaui, written in the mid to late $12^{\text {th }}$ century, we encounter a different type of potentially disruptive sound. This miracle at the saint's shrine is said to be witnessed by all who were present at the beginning of the procession on Saint Olav's day, and for the attentive reader the text evokes a clearly audible sound that is described in such a way that it would have been heard by everyone present at the cathedral:

Also, when a year had passed, on Saint Olav's day, another girl won the same abundance of grace, her sinews were withered, and for more than five years her heels had been joined to her buttocks. With the aid of the faithful, she was carried before the door of the choir, and when the saint's most holy body was lifted for the procession, by a miraculous power a cracking [harsh creaking sound] of stretching sinews was heard, and she was healed. ${ }^{42}$

This miracle is interesting for several reasons, firstly because of the sensory, and particularly auditory, information given, secondly because it gives us specific information about space and movement, and thirdly because it gives us information about those present and the activity that took place in the church at the moment when the miracle occurred.

Several senses are called into play in this short narrative. Much of the information concerns what can be seen, for example the lifting of the saint's body, or rather the chest in which the body is kept. But the miraculous event itself is described as auditory, not visual. Those present for the feast could presumably hear what is described as a cracking sound when the girl's withered sinews were stretched. And it is this sound of stretching sinews which signifies that something miraculous is happening. The cracking noise, heard by those present, signifies a bodily transformation that has resulted from a divine intervention by

\footnotetext{
${ }^{38}$ Flanigan 2005, 706.

${ }^{39}$ Finucane 1977, 88.

${ }^{40}$ Vita sancti Brynolphi episcopi Scarensis cum processu eius canonizacionis, 172.

${ }^{41}$ Bailey 2013, 532-538.

${ }^{42}$ My translation based on Jiroušková 2014, 56; Phelpstead and Kunin 2001, 53.
} 
which the girl is released from her crippled and contracted state and altered into someone who is transformed and healed.

The proximity to the shrine and relics, and the tactile engagement, are important features in the stories of shrine side miracles. This yearning for proximity has also been pointed out in studies of other miracle collections, ${ }^{43}$ and it can be seen in several of the narratives I have discussed here. Concerning the example from the miracles of St. Olav, it is relevant to mention that St. Olav's medieval shrine was in an elevated position behind the main altar in Nidarosdomen in Trondheim. In this strikingly auditory miracle, the girl is carried to the door of the choir. ${ }^{44}$ The healing is told to occur in a situation where spatial dimensions and the acts of lifting and moving seem to be of central significance. The miracle describes a communal effort to bring the girl towards the holy relics of the saint. She is lifted by the faithful and carried to the border of a sacred, prohibited space, that is, to the door of the choir, where she is audibly healed as the saint's body is lifted to start the procession. There seems to be a symbolic correspondence between these acts. The saint is lifted and moved from his altar, and at the same time moves to heal the child, who on her part is lifted and moved towards the holy space where the saint miraculously unlocks her from the tied-up position she has been in, and presumably renders her able to move freely on her own. The presumption that this girl is completely healed is strengthened by the miracle texts placement and context in the miracle collection. It directly succeeds a miracle in the Fountains Abbey MS, where another crippled girl is said to walk out of the church after being healed. ${ }^{45}$ And it is this preceding miracle the text refers to when it initially states that she "won the same abundance of grace". 46

It is common in the shrine-side miracles I have studied that the congregation, the parents, or even the child who receives healing strive to get the petitioner, or the prospective miraculee, as close to the relics or tomb as possible, ideally touching the shrine, even by laying them on top of the tomb itself, like the father of a four-year-old does in the miracles of Brynolf. ${ }^{47}$ There are numerous miracles in which the child is placed on the shrine, sleeps on the tomb or next to it for an extended period in the hope of receiving divine intervention.

\section{The speaking and participating child}

A miracle that prominently features the child speaking and noisily interrupting the ongoing liturgical activities can be found in the late thirteenth century miracles of Saint Erik Plovpenning.

In the year of our lord 1273, while sleeping at the tomb of Saint Erik a deaf and mute boy saw a dove fly out of his grave. It then flew back to the boy and made the sign of the cross under his chin, saying: "Promise you will not swear falsely and you will be healed, and your first word will be: Blessed be the lord and the blessed Erik!" Then when the gospel was being read he shouted freely: "Blessed be etc.; I can now speak". During credo he shouted "Blessed be

\footnotetext{
${ }^{43}$ Gaposchkin 2010, 259; Lohfert Jørgensen, Laugerud and Skinnebach 2015, 56-58.

${ }^{44}$ This miracle is the $22^{\text {nd }}$ miracle found in the MS of Passio et miracula beati Olaui from Fountains Abbey. The manuscript contains 28 miracles not found in any other version of Passio et miracula beati Olaui. For more on this see: Jiroušková 2010, 236-237.

${ }^{45}$ Passio et miracula beati Olaui Jiroušková 2014, 56.

46 “[...] consimilis gratie largitatem altera puella promeruit:[...]”: Jiroušková 2014, 56.

${ }^{47}$ Vita sancti Brynolphi episcopi Scarensis cum processu eius canonizacionis, Fant 1976, 144, 171.
} 
etc.; now I can hear". He was asked what his name was, and he said: "I do not know because I have been deaf". And he was called Erik. Witnesses to this were Andreas, abbot of the All saints' abbey in Lund, Abbot Johannes of Næstved and Lindig, the seneschal of the king. ${ }^{48}$

Of the examples I have discussed in this article, this miracle features the loudest child, and it is also the miracle in which the author brings us the closest to the child's own perspective. Here the author of the text takes us inside the boy's vision, we hear him speak, and we are presented with a boy so marginal that he does not know his name, nor is he presented as travelling with anyone who can supply it, and so he is named after the saint.

As with the three-year-old child in the miracle connected with St Niels of Århus we here have a child sleeping at the shrine, that is, an instance of incubation. This boy is also presented as experiencing a dream vision while sleeping. While the more common vision found in the Nordic miracles would consist of the saint talking, sometimes showing him- or herself to the sleeper, a dove functions as messenger in this narrative. The dove makes the sign of the cross under the boy's chin, presumably with its wings, before conveying the message that if he promises not to swear falsely, he will be healed.

There are some puzzling elements in the accounting of this miracle. It is interesting - but not surprising - that in his vision the deaf and mute boy I said to hear the dove, possibly a symbol of the Holy Spirit, speak. His deafness is in other words not noted to be a hindrance in the vision. However, when he is asked about his name, he answers that he has no name because he has been deaf. This may imply that he has not been able to read or communicate in any way. When he is healed we are not only told that he hears, he is also immediately and miraculously capable of understanding and using spoken language.

In the Nordic material there are examples of deaf and mute children who are described as praying at the shrines with loud lamentation. ${ }^{49}$ The boy in our example is presented as sleeping, thus not disturbing anyone or anything while he is waiting and hoping for the miracle at the shrine. When the miracle happens, he is, however, straight out noisy, and thus potentially the child causing the most significant disruption of the children I have discussed in this article. The boy shouts twice in the middle of mass, repeating the formula given to him in the vision. As the beneficiary of a miraculous cure he is praising the lord and the saint and then announcing to those present the nature of his healing-miracle. He can speak; he can hear.

It is interesting to note the timing of this formerly deaf and mute boy's outbursts; he speaks as the gospel is being read, and he hears when credo is being recited. One may have expected a reversed sequence, in which his acts functioned as a direct confirmation of the liturgy in some way, with him hearing the reading of the gospel and speaking as the credo is being recited. However, the miracle is told with speech preceding hearing.

The information we are given about the liturgical activities happening simultaneously with this miracle seems to place it during the liturgy of the word - on a Sunday or a feast day. This would mean that the miracle may have taken place on a day with a larger audience to witness and, in this case, hear the miracle happen. And there are indeed some rather important witnesses to the auditorily documented miracle. The healing of the deaf boy is said to be witnessed by elite members of the society, including the king's seneschal and the abbots of two

\footnotetext{
${ }^{48}$ My translation based on: De miraculis Sancti Erici Regis Danorum, 443-444; Olrik 1893, 400.

${ }^{49}$ Passio et miracula beati Olaui, Jiroušková 2014, 37-38.
} 
convents, which means that this is a story of a marginal child that may have functioned as an example also for the powerful.

It is the dramatic moment of healing in the narratives that most potently signifies the transformation of the child miraculees from marginal persons with little prospect of social agency and success to healed and thus empowered individuals who can play productive roles in society. And it should be noted that the disruptive moments of, say, cracking sinews or shouting from a formerly deaf and mute boy, do not seem to be described as severe disturbances leading to disorder or chaos. On the contrary, they rather seem to be restorations, or reestablishments, of order by dispelling the disabling condition in ways that could be heard or observed, often accompanied by descriptions of the child engaging in activities that were formerly out of reach. ${ }^{50}$

\section{Concluding remarks}

The miracle stories I have studied give the impression of a dense layering of activity. On the one hand liturgy forms a background for the miracle-seekers waiting at the shrine, and on the other hand their own sounds and activities, including those of young and sick children, form a background to the ongoing liturgical activities. Furthermore, while the liturgy plays an important part in the miracle narratives, the same narratives would, when recorded in legendaries, themselves become part of the liturgical celebration as they were read at Matins, mealtimes and the saints' feasts. Through these readings they functioned as models describing and prescribing the actions that should be carried out by the ones seeking the intercession of a saint. ${ }^{51}$

Miracles were recorded and read aloud in an effort to both convert and strengthen faith. ${ }^{52}$ Regarding hagiography from other regions, it has been claimed that tales about children in particular are windows into children's contribution to, or at least utilization in, the process of Christianisation and the establishment of cults. ${ }^{53}$ Children often played an important role in the activities associated with the establishment of a new cult, taking part in processions, feasts and ceremonies. ${ }^{54}$ In addition, it has been suggested that the noisy supplications of the pilgrims mentioned in numerous miracles are responding to a ritual mandate and therefore become part of the liturgical action. ${ }^{55}$ If we accept this premise, we have to acknowledge that also the actions of children found in miracle narratives become part of the liturgy. These children might seem disruptive to a modern reader, and others have found medieval examples of both children's disruptive behaviour in church being complained about, ${ }^{56}$ and miracle-seekers and miracles being seen as a disturbing element in themselves. ${ }^{57}$ However in my Nordic sample I find that these child miraculees are not presented as disruptive. They might interrupt and draw attention, but they seem to conform to prescribed forms of devotion and sometimes

\footnotetext{
${ }^{50}$ Kuuliala 2013, 131-135.

${ }^{51}$ Ihnat 2014, 67.

${ }^{52}$ Ward 1987, 29-31.

${ }^{53}$ Horn 2007, 265.

${ }^{54}$ Goodich 2007, 98.

${ }^{55}$ Flanigan 2005, 703.

${ }^{56}$ Orme 2017, 320; Orme 2001, 209-211.

${ }^{57}$ Bartlett 2013, 336-337.
} 
even add new layers to the liturgical celebrations, functioning as exempla of God's grace and intervention.

With such perspectives in mind, shrine-side child healing miracles may be seen as narratives that could strengthen the church's appeal to adults, inspire devotion and faith, and contribute to laypeople's loyalty. This impact was possibly amplified by promoting dramatic miracle narratives that appealed to the emotions of adults by focusing on the suffering, pain and hopeless situations of marginalized, sick or disabled children. Questions of central importance for later studies and discussions therefore spring to mind: Is the disruptive and dramatic nature of the early Nordic miracles concerning children especially potent. Do they have the power to influence and shape the laypeople's devotion and investments in the church? And does the suffering of a young child hold a greater potential for moving the audience that hear or read the miracle?

What miracle stories like the ones I have explored here unquestionably supply, are images of children who were amongst those that occupied the physical space inside of churches and at shrines, during prayers and services. The stories give us an indication of how they moved in these spaces and how they made themselves seen and heard in this place where liturgical activity shaped the rhythms of the day and the year. They portray children in devotional activities, as both active and passive participants in pilgrimages; they give information about how clerics, monastics and custodians of shrines gave and limited access and attention to children; and they give us moving examples of parent-child relationships, for example when telling about parents who carry their children over long distances to access the shrine. By looking for how children are presented, acting and participating in these spaces, and by noting the bits of sensory information given in the narratives, we can add to our mental image of how these spaces functioned and also find new clues to the history of a group that has left us with fewer historical traces than many others.

Rakel Igland Diesen

Norwegian University of Science and Technology (NTNU), Trondheim

rakel.diesen@ntnu.no 


\section{BIBLIOGRAPHY}

Ancient sources

Acta et processus canonizacionis beate Birgitte. Edited by Isak Collijn. 1924. Vol. 1, Samlingar utgivna av Svenska fornskriftsällskapet, Uppsala.

"De miraculis Sancti Erici Regis Danorum". In Vitae Sanctorum Danorum, edited by M. Cl Gertz. 1908, København.

"De Vita et Miraculis B. Nicholai Arusiensis", in Vitae Sanctorum Danorum, edited by M. Cl Gertz. 1908, København.

"Miracula S. Erici Regis et Martyris", in Fant, Erik Michael. 1828, Scriptores rerum Svecicarum medii aevi 2:1, Uppsala.

"Passio sancti Kanuti regis et martyris", in Vitae Sanctorum Danorum, edited by M. Cl Gertz. 1908, København.

"Passio et miracula beati Olaui", in Der heilige Wikingerkönig Olav Haraldsson und sein hagiographisches Dossier: Text und Kontext der Passio et miracula beati Olaui (mit kritischer Edition): Bd. 2: Edition und Bildmaterial. Jiroušková, Lenka. 2014, Leiden.

"Sancti Willelmi Abbatis vita et miracula", in Vitae Sanctorum Danorum, edited by M. Cl Gertz. 1908, København.

"Vita sancti Brynolphi episcopi Scarensis cum processu eius canonizacionis", in Scriptores rerum Svecicarum medii aevi 3:2. edited by Erik Michael Fant, Erik Gustav Geijer, Johan H Schröder 1876, Uppsala.

\section{Modern sources}

Aldrin V. 2015: "Parental Grief and Prayer in the Middle Ages: Religious Coping in Swedish Miracle Stories", Collegium: Studies Across Disciplines In The Humanities And Social Sciences 18, 82-105.

Bailey A.E. 2013: "Lamentation Motifs in Medieval Hagiography", Gender and History 25 (3), 529-544. doi: 10.1111/1468-0424.12026.

Bailey A.E. 2017: "Miracle children: medieval hagiography and childhood imperfection", The Journal of Interdisciplinary History 47 (3), 267-285. doi: 10.1162/JINH_a_01012.

Bartlett R. 2013: Why can the dead do such great things?: saints and worshippers from the martyrs to the Reformation, Princeton, N.J.
Collijn I. 1924: Acta et processus canonizacionis beate Birgitte. Vol. 1, Samlingar utgivna av Svenska fornskriftsällskapet, Uppsala.

Craig L.A. 2009: Wandering Women and Holy Matrons: Women as Pilgrims in the Later Middle Ages, Studies in Medieval and Reformation Traditions Ser, Leiden.

Fant E.M. 1828: Scriptores rerum Svecicarum medii aevi 2:1, Uppsala.

Fant E.M., Geijer E.G., Schröder J.H. 1876: Scriptores rerum Svecicarum medii aevi 3:2, Uppsala.

Finucane R.C. 1977: Miracles and pilgrims: popular beliefs in medieval England, London.

Finucane R.C. 1997: The Rescue of the Innocents: endangered children in medieval miracles, New York.

Flanigan C.C., Ashley K. and Sheingorn P. 2005: "Liturgy as social performance: Expanding the definitions", in E.A. Matter and T.J. Heffernan (eds.), The Liturgy of the medieval church, Kalamazoo.

Fröjmark A. 1997: "Barn och ungdomar i medeltida mirakelberättelser", Kalmar Län: Årsbok För Kulturhistoria Och Hembygdsvård 81, 29-36.

Fröjmark A. 2012: "Childbirth Miracles in Swedish Medieval Miracle Collections", JHSex 21 (2), 297 312. doi: 10.1353/sex.2012.0028.

Gaposchkin M.C. 2010: "Place, Status, and Experience in the Miracles of Saint Louis", crm (19), 249-266. doi: 10.4000/crm.12011.

Gertz M.Cl. 1908: Vitae Sanctorum Danorum, København.

Goodich M. 1995: Violence and miracle in the fourteenth century: private grief and public salvation, Chicago.

Goodich M. 2007: Miracles and wonders: the development of the concept of miracle, 1150-1350, Church, faith, and culture in the Medieval West, Aldershot.

Hahn C. 1997: "Seeing and believing: the construction of sanctity in early-Medieval saints and shrines, (Approaches to Early-Medieval Art)", Speculum 72 (4), 1079. doi: 10.2307/2865959.

Horn C.B. 2007: "The Lives and Literary Roles of Children in Advancing Conversion to Christianity: Hagiography from the Caucasus in Late Antiquity and the Middle Ages", ChHist 76 (2), 262-297. 
Ihnat K. 2014: "Marian Miracles and Marian Liturgies in the Benedictine Tradition of Post-Conquest England", in M.M. Mesley and L.E. Wilson (eds.), Contextualizing miracles in the Christian West, 1100-1500: new historical approaches, Oxford.

Jiroušková L. 2010: "Textual Evidence for the Transmission of the Passio et miracula beati Olaui Prior to 1200 and its Later Literary Transformations", in I. H. Garipzanov and H. Antonsson (eds.), Saints and their lives on the periphery: veneration of saints in Scandinavia and Eastern Europe (c. 1000-1200), Turnhout.

Jiroušková L. 2014: Der heilige Wikingerkönig Olav Haraldsson und sein hagiographisches Dossier: Text und Kontext der Passio et miracula beati Olaui (mit kritischer Edition): Bd. 2: Edition und Bildmaterial, Vol. 46/2, Mittelateinische Studien und Texte, Leiden.

Krötzl C. 1989: "Parent-child relations in medieval Scandinavia according to Scandinavian miracle collections", Scandinavian Journal of History 14 (12), 21-37.

Krötzl C. 1994: Pilger, Mirakel und Alltag: Formen des Verhaltens im skandinavischen Mittelalter (12.15. Jahrhundert), Vol. 46: Shs.

Kuuliala J. 2013: "Disability and social integration: constructions of childhood impairments in thirteenthand fourteenth-century canonisation processes", Jenni Kuuliala.

Lohfert J., Henrik H., Laugerud H. and Skinnebach L.K. 2015: The Saturated sensorium: principles of perception and mediation in the Middle Ages, Aarhus.

Mesley M.M. and Wilson L.E. 2014: Contextualizing miracles in the Christian West, 1100-1500: new historical approaches, Vol. 32: Society for the Study of Medieval Languages and Literature.
Metzler I. 2006: Disability in medieval Europe: thinking about physical impairment during the High Middle Ages, c. 1100-1400, Vol. 5, Routledge studies in medieval religion and culture, London.

Metzler I. 2013: A social history of disability in the middle ages: cultural considerations of physical impairment, 1st ed. Vol. 20, Routledge studies in cultural history, New York.

Myrdal J and Bäärnhielm G. 1994: Kvinnor, barn and fester i medeltida mirakelberättelser: med en katalog över svenska mirakelberättelser och en nyöversättning av Brynolfsmiraklerna, Vol. 19, Skrifter från Skaraborgs länsmuseum, Skara.

Nugent P.J. 2001: "Bodily Effluvia and Liturgical Interruption in Medieval Miracle Stories", HR 41 (1), 49-70. doi: 10.1086/463659.

Olrik H. 1893: Danske helgeners levned, Skrifter (Selskabet til historiske kildeskrifters oversattelse), København.

Orme N. 2001: Medieval Children, New Haven.

Orme N. 2017: "Children in medieval England", in R. Aasgaard and C. Horn (eds.), Childhood in History: Perceptions of Children in the Ancient and Medieval Worlds, Routledge.

Phelpstead C.L. and Kunin D. 2001: A History of Norway and the Passion and Miracles of the Blessed Óláfr: Viking Society for Northern Research (UCL).

Skórzewska J.A. 2008: 'Sveinn Einn Ungr Fell Í Sýruker': Medieval icelandic children in vernacular miracle stories, Leiden, Boston.

Vauchez A. 1997: Sainthood in the later Middle Ages, Translated by Jean Birrel, Cambridge.

Ward B. 1987: Miracles and the medieval mind: theory, record and event, 1000-1215, Rev. ed. Aldershot.

Zottl C.M. 2006: “Quae voces audio?”, Concilium medii aevi 9, 1-21. 